Relations industrielles

Industrial Relations

\title{
The Canadian Economic System, by André Raynauld, The MacMillan Co. of Canada Ltd., Toronto, 1967, 440 pages.
}

\section{Jean Sexton}

Volume 24, numéro 1, 1969

URI : https://id.erudit.org/iderudit/028001ar

DOI : https://doi.org/10.7202/028001ar

Aller au sommaire du numéro

Éditeur(s)

Département des relations industrielles de l'Université Laval

ISSN

0034-379X (imprimé)

1703-8138 (numérique)

Découvrir la revue

Citer ce compte rendu

Jean Sexton (1969). Compte rendu de [The Canadian Economic System, by André Raynauld, The MacMillan Co. of Canada Ltd., Toronto, 1967, 440 pages.]

Relations industrielles / Industrial Relations, 24(1), 220-221.

https://doi.org/10.7202/028001ar

Tous droits réservés @ C Département des relations industrielles de l'Université Laval, 1969
Ce document est protégé par la loi sur le droit d'auteur. L’utilisation des services d'Érudit (y compris la reproduction) est assujettie à sa politique d'utilisation que vous pouvez consulter en ligne.

https://apropos.erudit.org/fr/usagers/politique-dutilisation/ 
Evolution économique et salut de l'homme, par M. Parodi, A. Bonety, A. Souques, G. Couvreur, P. de Surgy, Les Editions Ouvrières, Paris, 1968, 348 pages.

L'ACO est d'abord un mouvement d'action catholique dont l'objectif premier est "l'évangélisation" du monde ouvrier; mais celle-ci ne peut être menée à bien qu'en reconnaissant l'existence et la spécificité d'une culture ouvrière:

«L'expression et la reconnaissance de cette culture de type ouvrier, lit-on dans la notice de présentation, nous paraissent capitales pour que l'Evangile s'acclimate au monde ouvrier. Cet humanisme nouveau que porte le mouvement ouvrier est appel à inventer de nouvelles expressions de l'existence chrétienne. Comment et dans quelles démarches profondes les travailleurs peuvent-ils vivre une charité qui soit d'extension politique, une espérance qui assume leur projet sur l'avenir humain, une foi qui retrouve Dieu dans leur volonté de sauver l'homme ?... L'évangélisation du monde ouvrier est une avancée collective des travailleurs vers le Seigneur; quels rapports peut-on déceler entre le dynamisme humain d'une classe s'exprimant dans le mouvement ouvrier et la croissance du royaume de Dieu? Des militants ouvriers chrétiens, participant depuis des dizaines d'années à la lutte ouvrière ont la conviction que cette histoire humaine rejoint le dessein de Dieu $\gg$.

Notre intention n'est pas de discuter ici du bien fondé de ces options, mais de souligner qu'elles représentent incontestablement un mouvement d'opinion certes minoritaire mais non sans influences et qui à ce titre ne saurait être passé sous silence dès que l'on entend étudier le mouvement ouvrier français contemporain.

Le livre débute par une série de témoignages sur la condition ouvrière. Tous s'accordent pour dénoncer le capitalisme comme la négation de valeurs démocratiques et chrétiennes. Il se termine sur une série de réflexions d'aumônier de l'ACO qu'il ne nous appartient pas de commenter ici. Entre ces deux parties s'intercalent les interventions de $\mathrm{M}$. René Bonety responsable du service économique de la CFDT et du professeur Maurice Parodi de l'Université d'Aix-enProvence sur \& le monde ouvrier dans le capitalisme contemporain $\gg$.
Cet ouvrage a selon nous le mérite de présenter un ensemble de réflexions synthétiques et critiques sur la société française d'aujourd'hui. L'enjeu de la lutte sociale ne se limite pas à l'accès à un niveau de consommation élargi, mais implique la définition d'un « Humanisme $\gg$ nouveau à laquelle croyants et incroyants peuvent contribuer sur le plan de valeurs communes.

\section{Bernard SOLASSE}

The Canadian Economic System, by André Raynauld, The MacMillan Co. of Canada Ltd., Toronto, 1967, 440 pages.

The teaching of economics in Canada is based almost entirely on foreign texts; and, while this allows the student to make use of the best texts available and helps to foster objective analysis, the disadvantage to the Canadian student is that he learns little about the economy of his own country.

This book includes descriptive material whose choice has been dictated primarily by the author's concern with teaching elementary causes in economics. While it may also be looked on as a general study of the Canadian economy, it necessarily differs in emphasis from a work intended as a balanced picture of a country.

There are big differences between the French and the English version of The Canadian Economic System. In the latter the author rewrote sections or chapters such as those on the Caisses populaires, the mortage loan and the trust companies, the pension funds and the consumer loan companies since in these particular fields the information brought out by the 1964 Report of the Royal Commission on Banking and Finance had to be taken into account.

Essentially this book contains four different parts. Part one entitled Income and Production deals with subjects such as the national accounts, the economic growth, the industrialization of Quebec, the economic fluctuations, the distribution of income, the labor market, the industrial organization and the anti-combines legislation. The second part of this book (Money and Finance) is specially interested in the money and the capital markets. The author then comes to the 
problem of public finance (Part 3) in dealing with taxation, public expenditures, social security, the fiscal policy and the public debt.

It is only in the final part (Foreign trade) that the author goes on the international scene by examining the Canadian foreign trade and the tariff policy and the problem of the balanced of payments.

Completed by a large bibliography and a good number of statistical tables, this book is a must for all those interested as well in economics as in labor relations in Canada.

\section{Jean SEXTON}

The Canadian Labour Market, by Arthur Kruger and Noah M. Meltz, Editors, Center for Industrial Relations, University of Toronto, 1968,312 pages.

Ce livre contient les résultats de recherches conduites par un groupe d'économistes à l'Université de Toronto sur des problèmes de main-d'oeuvre.

Le premier article d'Arthur Kruger, examine l'allocation des ressources humaines par les forces du marché et ce, de deux façons. D'abord, d'un point de vue théorique idéal; ensuite, d'après le degré d'éloignement du marché du travail de cet idéal théorique.

Le professeur Kruger discute également des politiques de main-d'oeuvre à la lumière de la théorie économique.

Il termine en mentionnant que les coûts et les avantages des programmes de main-d'oeuvre doivent être calculés d'après ce qu'ils représentent à la fois pour l'individu et pour la société.

Le deuxième article, celui de Samuel Hollander, présente le développement de la pensée en économique du XIXe siècle au sujet du fonctionnement du marché du travail.

Il montre que plusieurs questions économiques d'actualité étaient également discutées par les économistes des siècles passés. Ainsi, il présente les vues d'Adam Smith et de J. S. Mill sur l'influence du gouvernement et des syndicats sur la mobilité (ou l'immobilité) des travailleurs.
Hollander termine son article en soulignant que, pour les classiques, le chômage ne pouvait être que temporaire à cause de la flexibilité à la baisse des prix et des salaires monétaires.

Dans le troisième article, Yehuda Kotowitz montre comment les changements technologiques ont pour effet d'entraîner un déplacement des travailleurs. Il utilise un cadre théorique pour comparer la relation qui peut exister entre le progrès technique et le chômage. Par la suite, il présente des études empiriques sur l'expérience canadienne à ce sujet avant et après la deuxième guerre mondiale.

En terminant, le professeur Kotowitz montre que l'impact du progrès technique sur l'emploi est tout à fait différent selon que l'on considère l'économie globale ou que l'on considère les entreprises ou les industries. Le progrès technologique déplace les individus dit-il mais il permet simultanément la croissance de l'emploi et des salaires en général.

Dans son article, John Winder met en lumière une des questions les plus controversées parmi les économistes actuellement, à savoir si les hauts taux de chômage qui ont existé entre 1957 et 1963 étaient le résultat d'une demande globale déficiente ou de changements structurels dans l'économie.

Le professeur Winder définit le chômage structurel et montre comment il diffère des autres formes de chômage. Il classifie les différents types de chômage, cyclique, saisonnier, technologique, structurel et frictionnel, d'après leurs causes et d'après les politiques appropriées pour les combattre.

Selon lui, la lutte contre le chômage implique un dosage adéquat entre deux genres de politiques: les politiques traditionnelles fiscales et monétaires et les politiques de main-d'oeuvre. La question étant de savoir combien de chacune doit être utilisée.

Le chapitre suivant est un apport formidable à la recherche sur la maind'oeuvre en général. Il s'agit d'un recueil de toute l'information actuellement publiée au Canada sur les problèmes de main-d'oeuvre.

En plus d'indiquer le contenu des diverses publications, l'auteur en fait la critique et souligne ce qu'il manque 